CRYSTALLOGRAPHIC COMMUNICATIONS

ISSN 2056-9890

\section{Crystal structure, Hirshfeld surface analysis and spectroscopic characterization of the di-enol tautomeric form of the compound 3, $3^{\prime}$-[(2-sulfan- ylidene-1,3-dithiole-4,5-diyl)bis(sulfanediyl)]- bis(pentane-2,4-dione)}

Keysha T. Cordero Giménez, Victoria Y. Soto Díaz, Jean C. González Espiet, Alexis Lavín Flores, Jesbaniris Bas Concepción, Kevin E. Rivera Cruz, Dara L. Rodríguez Ayala and Dalice M. Piñero Cruz*

Department of Chemistry, University of Puerto Rico, Rio Piedras Campus, San Juan, 00927, Puerto Rico. *Correspondence e-mail: dalice.pinero@upr.edu

The reaction between $[\mathrm{TBA}]_{2}\left[\mathrm{Zn}(\mathrm{dmit})_{2}\right]$ and 3-chloro-2,4-pentanedione yielded single crystals of the title compound, $\left(3 E, 3^{\prime} E\right)-3,3^{\prime}-[(2$-sulfanylidene1,3-dithiole-4,5-diyl)bis(sulfanediyl)] bis(4-hydroxypent-3-en-2-one), $\mathrm{C}_{13} \mathrm{H}_{14} \mathrm{O}_{4} \mathrm{~S}_{5}$, after solvent evaporation. The title compound crystallizes in the triclinic space group $P \overline{1}$ with two molecules related by an inversion center present in the unit cell. The central thione ring moiety contains a carbon-carbon double bond covalently linked to two sulfoxide substituents located outside of the plane of the ring. The $\mathrm{S}-\mathrm{C}-\mathrm{C}-\mathrm{S}$ torsion angles are $-176.18(8)$ and $-0.54(18)^{\circ}$. Intramolecular hydrogen bonds occur within the two dione substituents $(1.67-1.69 \AA)$. Adjacent asymmetric units are linked by $\mathrm{C}-\mathrm{H} \cdots \mathrm{S}(2.89-2.90 \AA), \mathrm{S} \cdots \mathrm{S}$ [3.569 (1) $\AA]$ and $\mathrm{O} \cdots \mathrm{H}[2.56-2.66 \AA$ between non-stacked thione rings] short contacts.

\section{Chemical context}

Dithiolene systems (McCleverty et al., 1968) are a versatile family of compounds in coordination chemistry because of their redox non-innocent behavior (Eisenberg et al., 2011). These compounds are electronically flexible and contribute to the stability of several redox processes observed in metal complexes, which are not necessarily 'metal-based' (Stiefel, 2004; Periyasamy et al., 2007). Their electronic spin states can easily be clarified with the combined insights afforded by spectroscopic data, X-ray crystallography and computational analysis (Eisenberg et al., 2011; Yan et al., 2013; Lyaskovskyy et al., 2012). Dithiolene derivatives such as tetrathiafulvenylacetylacetonate (TTFSacacH), synthesized by Lorcy et al. (2001), have been reported as electroactive ligands with interesting redox properties. Most of these compounds employ the zinc-thiolate complex bis(tetrabutylammonium) bis(1,3dithiole-2-thione-4,5-dithiolato)zinc(II), $[\mathrm{TBA}]_{2}\left[\mathrm{Zn}(\mathrm{dmit})_{2}\right]^{2-}$ (Comerlato et al. 2002), as a key starting material to achieve the synthesis of interesting metal complexes.

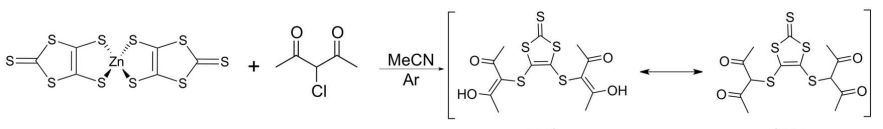

enol

keto

Herein, the reduction of the $\left[\mathrm{Zn}(\mathrm{dmit})_{2}\right]^{2-}$ dithiolene complex is utilized to aid the formation of a novel thiocarbonyl compound by its reaction with 3-chloro-2,4-penta- 
nedione (Cl-acac) to yield the title compound $\left(3 E, 3^{\prime} E\right)-3,3^{\prime}$ [(2-sulfanylidene-1,3-dithiole-4,5-diyl)bis(sulfanediyl)]bis(4hydroxypent-3-en-2-one), the di-enol tautomer of 3,3'-[(2sulfanylidene-1,3-dithiole-4,5-diyl)bis(sulfanediyl)]bis(pentane2,4-dione). The electrophilic nature of the acetylacetone (acac) motif and the high electron density on the sulfur atoms drive the nucleophilic substitution to completion. The title compound is a double $\beta$-dicarbonyl compound that contains two acetylacetone moieties, which are found in their enolic form in the solid state. Concerning the reactivity of the title compound, it is able to undergo acid or base-catalyzed $\alpha$ hydrogen substitution reactions, in which the rate-determining step is the formation of the enol or enolate anion (Shapet'ko et al., 1975). Compared to the acid-catalyzed process, the selfenolization of most ketones is negligible. The double $\beta$ dicarbonyl compound described herein also undergoes tautomerization; however, in the solid phase, the enol tautomer predominates in this equilibrium as it is stabilized relative to the keto form via resonance through the conjugated $\pi$-system and by intramolecular hydrogen bonding in the solid-state (Drexler et al. 1976; Seco et al. 1989). This aspect is confirmed by its FT-IR and NMR spectra.

\section{Structural commentary}

The title compound crystallizes in the triclinic space group $P \overline{1}$ with one molecule in the asymmetric unit (Fig. 1, Table 3). Its chemical structure consists of two 4-hydroxy-3-penten-2-one units connected to a 1,3-dithiol-1-thione ring moiety through a $\mathrm{C}-\mathrm{S}$ single bond. In the unit cell, two molecules are related by an inversion center. The central thione ring is conformed by a $\mathrm{C} 2=\mathrm{C} 3$ carbon-carbon double bond, which is in the same plane as the $\mathrm{C} 1=\mathrm{S} 1$ bond characteristic of the thione substituent. The angles $\mathrm{C} 2-\mathrm{S} 3-\mathrm{C} 6$ and $\mathrm{C} 3-\mathrm{S} 4-\mathrm{C} 11$ are $101.45(7)$ and $103.72(7)^{\circ}$, respectively. The torsion angles $\mathrm{S} 4-\mathrm{C} 3-\mathrm{C} 2-\mathrm{S} 3$ and $\mathrm{S} 2-\mathrm{C} 2-\mathrm{C} 3-\mathrm{S} 5$ are -176.18 (8) and $-0.54(18)^{\circ}$, respectively; the difference in the torsion angles is due to the effects of steric hindrance from the 4-hydroxy-3-

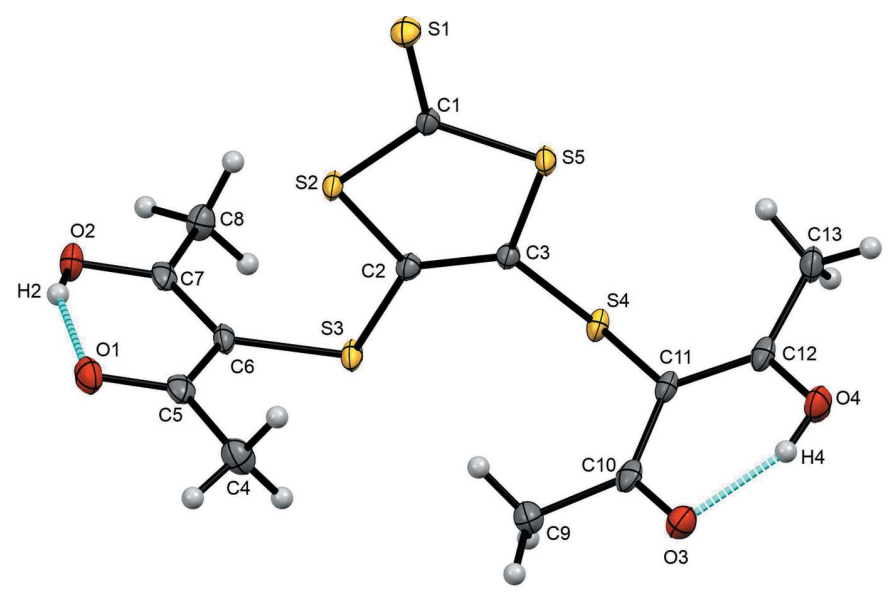

Figure 1

The title compound with displacement ellipsoids drawn at $50 \%$ probability level and hydrogen bonds $(\mathrm{O}-\mathrm{H} \cdots \mathrm{O})$ in the asymmetric unit indicated. penten-2-one moiety. The $\mathrm{S} 4-\mathrm{C} 3$ and $\mathrm{S} 3-\mathrm{C} 2$ bond lengths are 1.7608 (16) and 1.7679 (16) $\AA$, respectively.

\section{Supramolecular features}

The title compound exhibits numerous intermolecular interactions, namely four $\mathrm{C}-\mathrm{H} \cdots \mathrm{O}$, three $\mathrm{C}-\mathrm{H} \cdots \mathrm{S}$, three $\mathrm{C} \cdots \mathrm{O}$, one S $\cdots \mathrm{C}$, and one S..S interaction (Fig. 2, Tables 1 and 2). The five-membered thiocarbonyl-containing rings lie almost parallel to the $c$ axis and extend in a sheet-like fashion, forming a network that propagates along the axis with all rings following the same orientation. The sheets are linked by outof-plane $\mathrm{C} 13-\mathrm{H} 13 B \cdots \mathrm{S} 1$ short contacts, generating stacks along the $a$ axis with $\mathrm{S} \cdots \mathrm{S}$ short contacts between adjacent molecules $\left[\mathrm{S} 5 \cdots \mathrm{S} 5^{\text {iv }}=3.5688(6) \AA\right]$. In addition, the nucleophilic atom $\mathrm{S} 3$ is oriented towards the electrophilic C5, leading to an $\mathrm{S} 3 \cdots \mathrm{C} 5^{\mathrm{iii}}[3.471(2) \AA]$ contact, further contributing to the extension of the network along the $c$-axis direction. Molecules of the title compound also associate with neighboring molecules above and below the thiocarbonyl ring planes through the acac backbone by $\mathrm{C} 4-\mathrm{H} 4 \cdots \mathrm{S} 1$ and $\mathrm{C} 9-\mathrm{H} 9 \cdots \mathrm{S} 1$ contacts. The acac backbone lies nearly perpendicular to the rings, and there are several key interactions between the

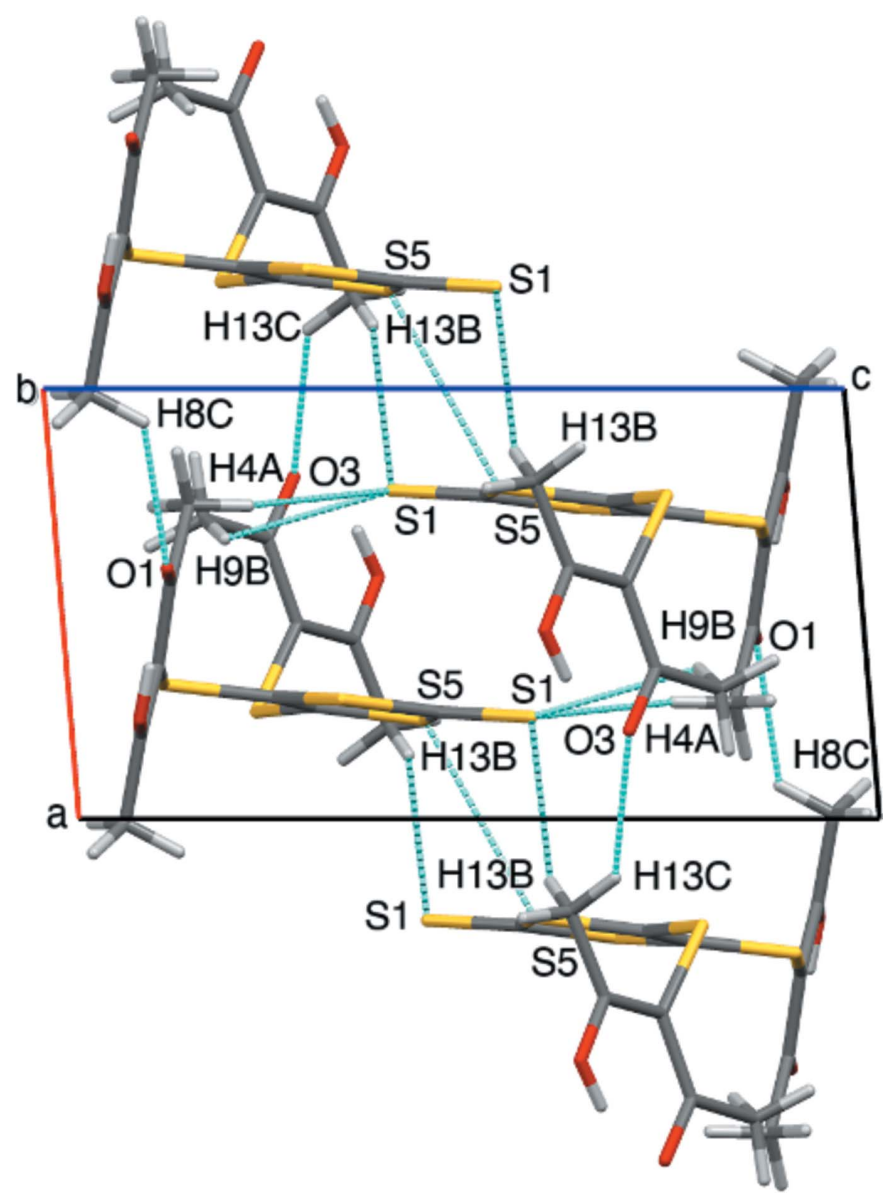

Figure 2

Crystal packing of the title compound, indicating the intermolecular $\mathrm{O} \cdots \mathrm{H}-\mathrm{C}, \mathrm{O} \cdots \mathrm{C}$ and $\mathrm{S} \cdots \mathrm{C}, \mathrm{C}-\mathrm{H} \cdots S$ and $S \cdots \mathrm{S}$ short contacts, viewed along the $b$ axis. 
Table 1

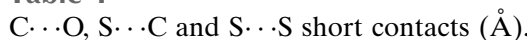

\begin{tabular}{llll}
\hline $\mathrm{C} 10 \cdots \mathrm{O} 1^{\mathrm{i}}$ & $3.178(2)$ & $\mathrm{S} 3 \cdots \mathrm{C} 5^{\mathrm{iii}}$ & $3.471(2)$ \\
$\mathrm{C} 12 \cdots \mathrm{O} 4^{\mathrm{ii}}$ & $3.180(2)$ & $\mathrm{S} 5 \cdots \mathrm{S} 5^{\mathrm{iv}}$ & $3.5688(6)$ \\
$\mathrm{C} 13 \cdots \mathrm{O} 4^{\mathrm{ii}}$ & $3.219(2)$ & & \\
\hline
\end{tabular}

Symmetry codes: (i) $x, y-1, z$; (ii) $-x+1,-y,-z+1$; (iii) $-x+1,-y+1,-z+2$; (iv) $-x,-y+1,-z+1$.

Table 2

Hydrogen-bond geometry $\left(\AA \stackrel{\circ}{\circ}^{\circ}\right)$.

\begin{tabular}{lllll}
\hline$D-\mathrm{H} \cdots A$ & $D-\mathrm{H}$ & $\mathrm{H} \cdots A$ & $D \cdots A$ & $D-\mathrm{H} \cdots A$ \\
\hline $\mathrm{O} 2-\mathrm{H} 2 \cdots \mathrm{O} 1$ & 0.82 & 1.67 & $2.4228(17)$ & 151 \\
$\mathrm{O} 4-\mathrm{H} 4 \cdots \mathrm{O} 3$ & 0.82 & 1.69 & $2.4406(17)$ & 151 \\
$\mathrm{C} 13-\mathrm{H} 13 C \cdots \mathrm{O}^{\mathrm{v}}$ & 0.96 & 2.60 & $3.374(3)$ & 138 \\
$\mathrm{C} 8-\mathrm{H} 8 C \cdots \mathrm{O} 3^{\text {vi }}$ & 0.96 & 2.66 & $3.522(2)$ & 150 \\
$\mathrm{C} 8-\mathrm{H} 8 A \cdots \mathrm{O} 2^{\text {vii }}$ & 0.96 & 2.66 & $3.612(2)$ & 170 \\
$\mathrm{C} 8-\mathrm{H} 8 C \cdots \mathrm{O} 1^{\mathrm{v}}$ & 0.96 & 2.56 & $3.228(3)$ & 127 \\
$\mathrm{C} 9-\mathrm{H} 9 B \cdots \mathrm{S} 1^{\text {viii }}$ & 0.96 & 2.90 & $3.5184(19)$ & 123 \\
$\mathrm{C} 13-\mathrm{H} 13 B \cdots \mathrm{S} 1^{\text {iv }}$ & 0.96 & 2.89 & $3.7165(19)$ & 144 \\
$\mathrm{C} 4-\mathrm{H} 4 A \cdots \mathrm{S} 1^{\text {viii }}$ & 0.96 & 2.90 & $3.7987(19)$ & 156 \\
\hline
\end{tabular}

Symmetry codes: (iv) $-x,-y+1,-z+1$; (v) $x-1, y, z$; (vi) $x-1, y+1, z$; (vii) $-x,-y+2,-z+2 ;($ viii $)-x+1,-y+1,-z+1$.

carbonyl oxygen atoms (O1, O2, and O3) and neighboring methyl hydrogen atoms ( $\mathrm{H} 8 A$ and $\mathrm{H} 8 C$ ) with lengths in the range 2.56-2.66 $\AA$. However, atom O4 is not involved in any interactions with hydrogen atoms, and instead makes short contacts with both $\mathrm{C} 12$ and $\mathrm{C} 13$.

\section{Hirshfeld Surface Analysis}

The Hirshfeld surface (Spackman \& Jayatilaka, 2009) for the title compound mapped over $d_{\text {norm }}$ is shown in Fig. 3 while Fig. 4 shows the associated two-dimensional fingerprint plots (McKinnon et al., 2007), both generated with CrystalExplorer17 (Turner et al., 2017). Red spots on the Hirshfeld surface mapped over $d_{\text {norm }}$ in the color range -0.0820 to 1.5568 arbitrary units confirm the above-mentioned primary intermolecular contacts. The fingerprint plots are given for all

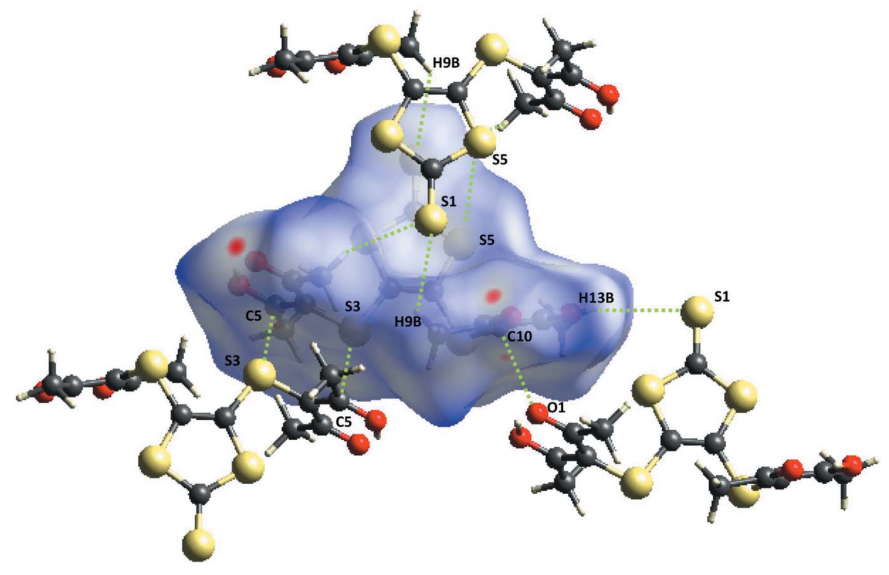

Figure 3

Hirshfeld surface of the title compound mapped over $d_{\text {norm }}$ with the four main intermolecular contacts in the crystal lattice shown.
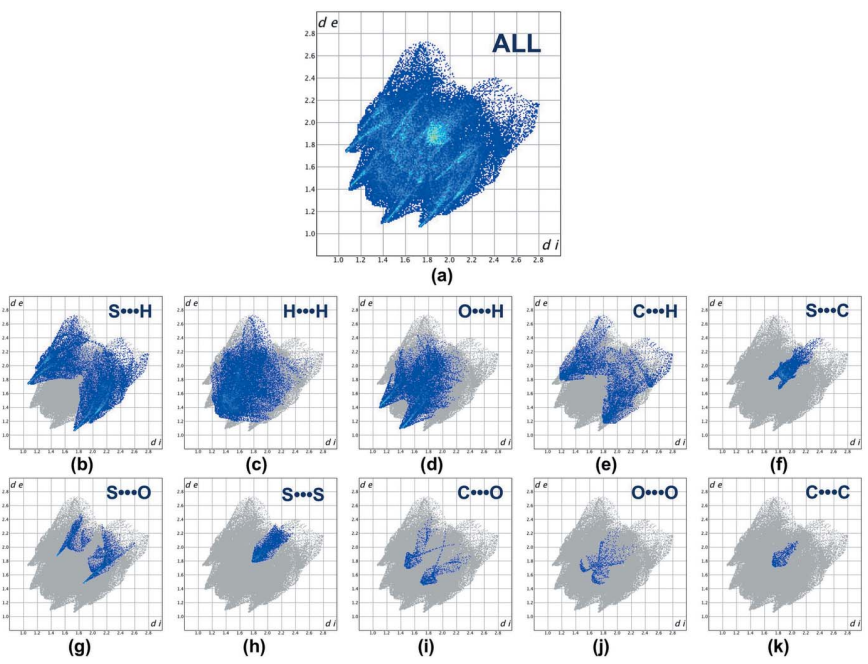

Figure 4

Full $(a)$ and individual $(b)-(m)$ two-dimensional fingerprint plots showing the ten intermolecular contacts present in the crystal structure.

contacts and those delineated into S...H/H...S (27.9\%; Fig. $4 b), \mathrm{H} \cdots \mathrm{H}(25.8 \%$; Fig. $4 c), \mathrm{O} \cdots \mathrm{H} / \mathrm{H} \cdots \mathrm{O}(19.5 \%$; Fig. $4 d)$, C $\cdots \mathrm{H} / \mathrm{H} \cdots \mathrm{C}(9.3 \%$; Fig. $4 e)$, S $\cdots \mathrm{C} / \mathrm{C} \cdots \mathrm{S}(4.9 \%$;

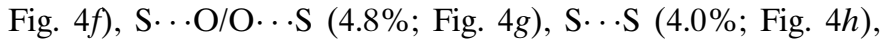
$\mathrm{O} \cdots \mathrm{C} / \mathrm{C} \cdots \mathrm{O}(2.0 \%$; Fig. $4 i)$, O $\cdots \mathrm{O}(1.1 \%$; Fig. $4 j)$, and C $\cdots \mathrm{C}$ $(0.7 \%$; Fig. $4 k)$ interactions. Thus, the Hirshfeld surface analysis indicates that the most significant contributions arise from $\mathrm{S} \cdot \mathrm{H}$ and $\mathrm{H} \cdot \cdots \mathrm{H}$ contacts.

\section{Database survey}

A search of the Cambridge Structural Database (CSD Version 5.40, September 2019 update; Groom et al., 2016) for the title compound revealed 46 hits comprising structures including metal complexes and organic compounds. Of the latter, 31 hits are for $\mathrm{C}-\mathrm{S}$ bicyclic compounds and four hits are for monocyclic $\mathrm{C}-\mathrm{S}$ crystal structures. Monocyclic structures related to the title compound are bis(5-(mesitylthio)-1,3-dithiole-2thione)-4,4'-disulfide dihydrate (LOBXEF; Cerrada et al., 1999), 4,4'-disulfanediylbis\{5-[(2,4,6-triisopropylphenyl)sulfanyl]-1,3-dithiole-2-thione\} (NUMXOJ; Cerrada et al., 2009) and 4,5-bis(2,4-dinitrophenylthio)-1,3-dithiole-2-thione (YISBOR; Qi et al., 1994 and YISBOR10; Qu et al., 1995). The dihedral angles in YISBOR/YISBOR10 and LOBXEF are similar to those exhibited by the title compound, unlike in NUMXOJ, which is completely different. For the mentioned compounds, the lack of $\mathrm{C}-\mathrm{H} \cdots \mathrm{O}$ and $\mathrm{C}-\mathrm{H} \cdots \mathrm{S}$ short contacts means they are not comparable to the title compound. The four comparative compounds show similar S...C short contacts, which involve the sulfur atoms of the thione ring and the carbon atoms from the substituents. In contrast to YISBOR/YISBOR10, the structures of LOBXEF and NUMXOJ exhibit an S...S short contact analogous to that in the title compound. The structure of NUMXOJ exhibits $\pi-\pi$ stacking of the thione rings of neighboring molecules, similar to the title compound, and unlike LOBXEF (in which 
$\pi-\pi$ stacking occurs between the benzene and thione rings) and YISBOR/YISBOR10 (where there $\pi-\pi$ stacking between the thione ring and one benzene ring).

\section{Synthesis and crystallization}

The synthesis of the title compound was carried out by refluxing 1 eq. of $[\mathrm{TBA}]_{2}\left[\mathrm{Zn}(\mathrm{dmit})_{2}\right]$ and 4 eq. of 3-chloro-2,4pentanedione in $100 \mathrm{~mL}$ of acetonitrile under argon for $1 \mathrm{~h}$, after which it was cooled and left under stirring overnight. Activated carbon was added and stirring continued for $1 \mathrm{~h}$. The resulting mixture was filtered and washed with cold acetonitrile. The solvent was evaporated under reduced pressure, and ethyl acetate was added to precipitate $\mathrm{ZnCl}_{2}$. The remaining solution was filtered, followed by evaporation of the solvent, giving a yellow crystalline solid (67.3\% yield). NMR analyses were performed on a Bruker AV-700 spectrometer using chloroform- $d\left(\mathrm{CDCl}_{3}\right)$ as solvent. The solvent signals at 7.26 and $77.00 \mathrm{ppm}$ were used as internal standards for proton and carbon, respectively. ${ }^{1} \mathrm{H}$ NMR $(700 \mathrm{MHz}$, $\left.\mathrm{CDCl}_{3}\right) \delta 15.40(s, 1 \mathrm{H}$, interchangeable $) 5.11(s, 1 \mathrm{H}$, interchangeable), $2.48(s, 12 \mathrm{H}) .{ }^{13} \mathrm{C}$ NMR $\left(176 \mathrm{MHz}, \mathrm{CDCl}_{3}\right) \delta$ 24.92, 102.30, 131.40, 197.78, 209.18.

\section{Spectroscopic Characterization}

Without basic catalysis, the self-enolization of most ketones is negligible and the keto form is favored almost exclusively (Drexler et al., 1976). However, $\beta$-dicarbonyl compounds, which can also undergo tautomerization, are stabilized in the enol tautomer via resonance of the conjugated $\pi$-system and intramolecular hydrogen bonding. Furthermore, the enol is the less polar of the two tautomers because the intramolecular hydrogen bond reduces the dipole-dipole repulsion of the two carbonyls in the keto form. The equilibrium of $\beta$-dicarbonyl compounds has been studied extensively and it has been shown that tautomeric interconversion between the diketo and enol forms is relatively slow and can be observed by NMR. Under normal conditions, the enolic form predominates in equilibrium (Egan et al., 1977). This effect was demonstrated to be solvent and concentration dependent. An NMR study of keto-enol tautomerism in $\beta$-dicarbonyl compounds revealed that for the unsubstituted and symmetrical $\beta$-dicarbonyl compound pentane-2,4-dione, the equilibrium constant at $310 \mathrm{~K}$ has a value of 2.95 with 93.3 enol \% (acetone exists as $0.00025 \%$ enol) (Schubert, 1960). In addition, as these compounds are progressively diluted with nonpolar solvents, the enol content of the system increases. The progressive dilution with more polar solvents than the solute was observed to increase the stability of the keto form.

In the case of the ${ }^{1} \mathrm{H}$ NMR study of the title compound in deuterated chloroform at $298 \mathrm{~K}$, the predominant form was observed to be the enol tautomer. NMR was used to confirm the underlying symmetry the title compound possesses in solution, in which the enol tautomer predominates, as can be observed in Fig. 5. The lowest frequency signal in the ${ }^{1} \mathrm{H}$ NMR spectrum integrates to twelve and corresponds to the methyl

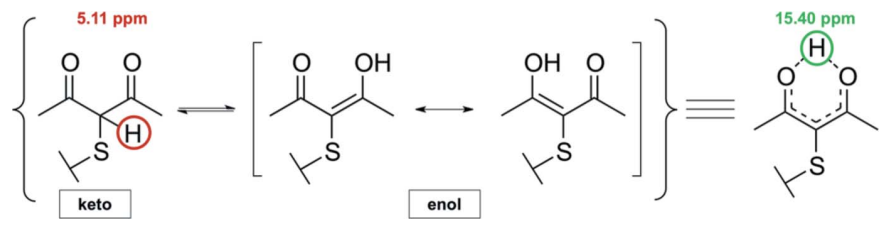

Figure 5

Tautomeric effect observed in the acetylacetonate portion of the title compound.

protons of the compound, indicating that the latter are chemically equivalent. Similarly, the enol form of the compound was observed crystallographically and in solution, exhibiting intramolecular hydrogen bonding and renders both methyl groups, as well as both carbonyls, chemically equivalent. When studying the proton spectrum, the conjugation in the six-membered pseudo-aromatic ring deshields the signal of the interchangeable proton, giving rise to a low field signal at $15.4 \mathrm{ppm}$ that is lost in the baseline. Looking further into the baseline at higher fields, around $5.1 \mathrm{ppm}$, it reveals a wide signal that is almost lost in the noise and that can be assigned to the interchangeable proton in the keto tautomer (Fig. 6). The formation of this hydrogen-bridge bond is promoted by the planar structure of the enol-carbonyl resonance system because this leads to an ideal spatial orientation of the hydroxy group and carbonyl group in order to construct a strong hydrogen-bridge bond. Therefore, the monoenolic form of a $\beta$-dicarbonyl compound has a planar, six-membered cyclic structure stabilized by resonance. Decreasing the concentration of the solute in non-polar solvents has been proven to increase the concentration of the enol tautomer. ${ }^{13} \mathrm{C}$ NMR spectrum displayed a single signal at $24.8 \mathrm{ppm}$ for the methyl carbons, and a single signal at $197.7 \mathrm{ppm}$ for the carbonyl carbons, supporting the statement that there is chemical equivalency between the methyl groups and, most importantly, between both carbonyl moieties. This effect has been previously demonstrated by comparing the ${ }^{13} \mathrm{C}$ NMR spectra of the enol forms of symmetrical and unsymmetrical derivatives of $\beta$-diketones, where a different chemical shift was observed for the two carbonyls in the unsymmetrical case (Shapet'ko et al., 1975). It is possible to conclude that the three

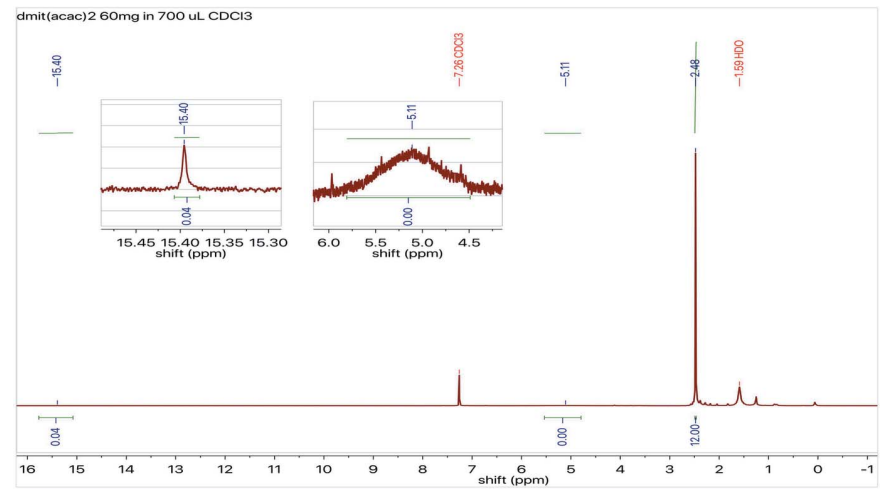

Figure 6

${ }^{1} \mathrm{H}$ NMR spectrum of the title compound with inserts of the baseline expansions near 15.4 and $5.1 \mathrm{ppm}$, respectively. 


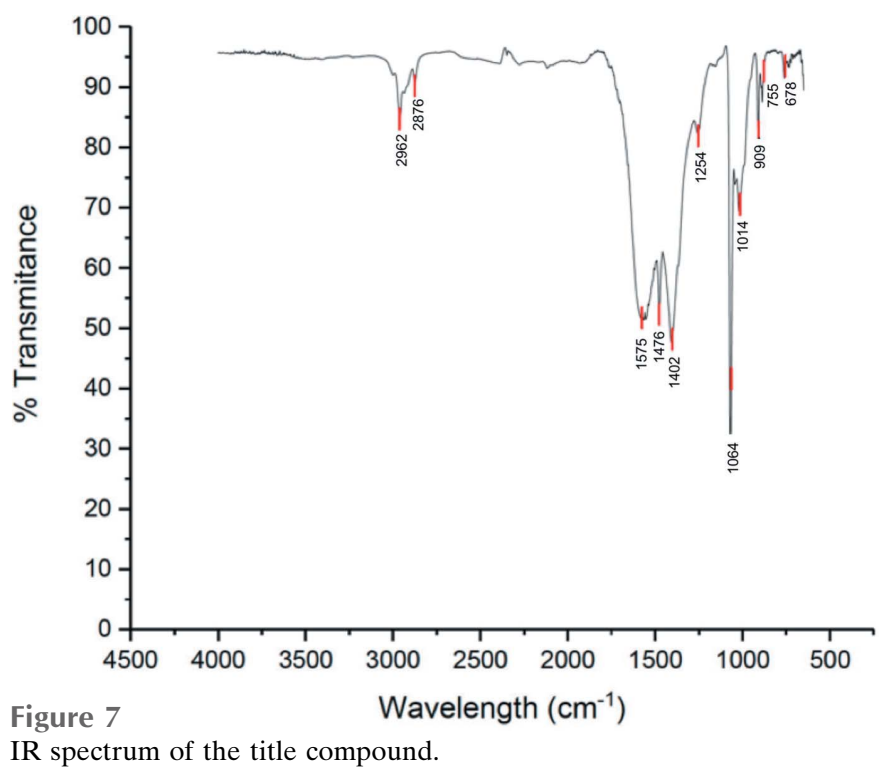

signals of the 2,4-pentanedione portion of the title compound, as well as the chemical shifts observed, are indicative of a symmetrical system that results from intramolecular hydrogen-bonding in the enol tautomer.

IR peaks at 2,962 and $2,876 \mathrm{~cm}^{-1}$ are assigned to the $\mathrm{C}-\mathrm{H}$ stretches (Fig. 7). The peaks between 1,575 and $1,402 \mathrm{~cm}^{-1}$ correspond to the $\mathrm{C}=\mathrm{C}$ bond in the enol form. Moreover, hidden under this peak there is also the $\mathrm{C}=\mathrm{O}$ stretch in the enol form, which is lowered by conjugation to the $\mathrm{C}=\mathrm{C}$ bond and the $\mathrm{O}$ atom of the $-\mathrm{OH}$ group, respectively. $\mathrm{OH}$ stretches for $\beta$-diketones are tabulated from 3,200 to $2,400 \mathrm{~cm}^{-1}$; however, in the case of symmetric acac compounds where the enol form predominates and the interchangeable hydrogen is located between the two carbonyls, the dipole change associated to the symmetric $\mathrm{OH}$ stretch is null, and the signal is minimal to non-existent. Thus, evidence from NMR and IR spectroscopy indicates that the compound exists almost entirely in its enol form.

\section{Refinement}

Crystal data, data collection and structure refinement details are summarized in Table 3. $\mathrm{H}$ atoms were included in geometrically calculated positions for the alkyl groups while the hydrogen atoms from $\mathrm{OH}$ groups were located from the difference-Fourier map and refined as riding: $\mathrm{O}-\mathrm{H}=0.82 \AA$, $\mathrm{C}-\mathrm{H}=0.93-0.98 \AA$ with $U_{\text {iso }}(\mathrm{H})=1.5 U_{\text {eq }}(\mathrm{O}, \mathrm{C}-\mathrm{methyl})$ and $1.2 U_{\mathrm{eq}}(\mathrm{C})$ for other $\mathrm{H}$ atoms.

\section{Funding information}

The authors acknowledge the facility of the Molecular Science Research Center (MSRC) and Materials Characterization Center (MCC) at the University of Puerto Rico for their assistance and instrumentation facilities. The National Science Foundation grant No. 1626103 is also acknowledged. KC is thankful to the Research Initiative for Scientific Enhancement (RISE) Program under grant No. 5R25GM061151-18.
Table 3

Experimental details.

\begin{tabular}{|c|c|}
\hline \multicolumn{2}{|l|}{ Crystal data } \\
\hline Chemical formula & $\mathrm{C}_{13} \mathrm{H}_{14} \mathrm{O}_{4} \mathrm{~S}_{5}$ \\
\hline$M_{\mathrm{r}}$ & 394.54 \\
\hline Crystal system, space group & Triclinic, $P \overline{1}$ \\
\hline Temperature $(\mathrm{K})$ & 100 \\
\hline$a, b, c(\AA)$ & $7.1843(1), 9.9198(1), 12.5230(2)$ \\
\hline$\alpha, \beta, \gamma\left({ }^{\circ}\right)$ & 84.319 (1), 83.574 (1), 69.151 (1) \\
\hline$V\left(\AA^{3}\right)$ & $827.11(2)$ \\
\hline$Z$ & 2 \\
\hline Radiation type & $\mathrm{Cu} K \alpha$ \\
\hline$\mu\left(\mathrm{mm}^{-1}\right)$ & 6.59 \\
\hline Crystal size $(\mathrm{mm})$ & $0.3 \times 0.28 \times 0.06$ \\
\hline \multicolumn{2}{|l|}{ Data collection } \\
\hline Diffractometer & Rigaku SuperNova HyPix3000 \\
\hline Absorption correction & $\begin{array}{l}\text { Multi-scan (CrysAlis PRO; Rigaku } \\
\text { OD, 2015) }\end{array}$ \\
\hline$T_{\min }, T_{\max }$ & $0.208,0.673$ \\
\hline $\begin{array}{l}\text { No. of measured, independent and } \\
\text { observed }[I>2 \sigma(I)] \text { reflections }\end{array}$ & $45972,3086,3034$ \\
\hline$R_{\text {int }}$ & 0.048 \\
\hline$(\sin \theta / \lambda)_{\max }\left(\AA^{-1}\right)$ & 0.606 \\
\hline \multicolumn{2}{|l|}{ Refinement } \\
\hline$R\left[F^{2}>2 \sigma\left(F^{2}\right)\right], w R\left(F^{2}\right), S$ & $0.027,0.073,1.05$ \\
\hline No. of reflections & 3072 \\
\hline No. of parameters & 206 \\
\hline $\mathrm{H}$-atom treatment & $\mathrm{H}$-atom parameters constrained \\
\hline$\Delta \rho_{\max }, \Delta \rho_{\min }\left(\mathrm{e} \AA^{-3}\right)$ & $0.37,-0.31$ \\
\hline
\end{tabular}

Computer programs: CrysAlis PRO (Rigaku OD, 2015), SHELXT2014/5 (Sheldrick, 2015a), SHELXL (Sheldrick, 2015b) and OLEX2 (Dolomanov et al., 2009).

\section{References}

Cerrada, E., Elipe, S., Laguna, M., Lahoz, F. \& Moreno, A. (1999). Synth. Met. 102, 1759-1760.

Cerrada, E., Moreno, A. \& Laguna, M. (2009). Dalton Trans. 34, 6825-6835.

Comerlato, N. M., Harrison, W. T. A., Howie, R. A., Low, J. N., Silvino, A. C., Wardell, J. L. \& Wardell, S. M. S. V. (2002). Acta Cryst. C58, m105-m108.

Dolomanov, O. V., Bourhis, L. J., Gildea, R. J., Howard, J. A. K. \& Puschmann, H. (2009). J. Appl. Cryst. 42, 339-341.

Drexler, E. \& Field, K. (1976). J. Chem. Educ. 53, 392-392.

Egan, W., Gunnarsson, G., Bull, T. E. \& Forsen, S. (1977). J. Am. Chem. Soc. 99, 4568-4572.

Eisenberg, R. \& Gray, H. (2011). Inorg. Chem. 50, 9741-9751.

Groom, C. R., Bruno, I. J., Lightfoot, M. P. \& Ward, S. C. (2016). Acta Cryst. B72, 171-179.

Lorcy, D. \& Bellec, N. (2001). Tetrahedron Lett. 42, 3189-3191.

Lyaskovskyy, V. \& de Bruin, B. (2012). ACS Catal. 2, 270-279.

McCleverty, J. A. (1968). Prog. Inorg. Chem. 10, 49-221.

McKinnon, J. J., Jayatilaka, D. \& Spackman, M. A. (2007). Chem. Commun. 37, 3814-3816.

Periyasamy, G., Burton, N., Hillier, I. H., Vincent, M., Disley, H., McMaster, J. \& Garner, C. (2007). Faraday Discuss. 135, 469-488.

Qi, F., Min-Hua, J., Zheng, Q., Jin-Hua, C., Hong, L., Wen-Tao, Y. \& Zhuang, Z. (1994). J. Mater. Chem. 4, 1041-1045.

Qu, Z., Cai, J., Fang, Q., You, X. \& Huaxue, J. (1995). Chin. J. Struct. Chem. 14, 318-321.

Rigaku OD (2015). CrysAlis PRO. Rigaku Oxford Diffraction, Yarnton, England.

Schubert, W. M. (1960). J. Chem. Educ. 37, 379-380.

Seco, M. (1989). J. Chem. Educ. 66, 779-782.

Shapet'ko, N., Berestova, S., Lukovkin, G. \& Bogachev, Y. (1975). Org. Magn. Reson. 7, 237-239.

Sheldrick, G. M. (2015a). Acta Cryst. A71, 3-8. 
Sheldrick, G. M. (2015b). Acta Cryst. C71, 3-8.

Spackman, M. A. \& Jayatilaka, D. (2009). CrystEngComm, 11, 19 32.

Stiefel, E. I. (2004). Editor. Progress in Inorganic Chemistry, Vol. 52, Dithiolene Chemistry: Synthesis, Properties and Applications, p. 52. Hoboken, NJ: John Wiley \& Sons, Inc.
Turner, M. J., McKinnon, J. J., Wolff, S. K., Grimwood, D. J., Spackman, P. R., Jayatilaka, D. \& Spackman, M. A. (2017). CrystalExplorer17.5. The University of Western Australia.

Yan, Y., Keating, C., Chandrasekaran, P., Jayarathne, U., Mague, J. T., DeBeer, S., Lancaster, K., Sproules, S., Rubtsov, I. \& Donahue, J. (2013). Inorg. Chem. 52, 6743-6751. 


\section{supporting information}

Acta Cryst. (2020). E76, 1427-1432 [https://doi.org/10.1107/S2056989020010695]

Crystal structure, Hirshfeld surface analysis and spectroscopic characterization of the di-enol tautomeric form of the compound 3,3'-[(2-sulfanylidene-1,3-dithiole-4,5-diyl)bis(sulfanediyl)]bis(pentane-2,4-dione)

Keysha T. Cordero Giménez, Victoria Y. Soto Díaz, Jean C. González Espiet, Alexis Lavín Flores, Jesbaniris Bas Concepción, Kevin E. Rivera Cruz, Dara L. Rodríguez Ayala and Dalice M. Piñero Cruz

Computing details

Data collection: CrysAlis PRO (Rigaku OD, 2015); cell refinement: CrysAlis PRO (Rigaku OD, 2015); data reduction: CrysAlis PRO (Rigaku OD, 2015); program(s) used to solve structure: SHELXT2014/5 (Sheldrick, 2015a); program(s) used to refine structure: SHELXL (Sheldrick, 2015b); molecular graphics: OLEX2 (Dolomanov et al., 2009); software used to prepare material for publication: OLEX2 (Dolomanov et al., 2009).

(3E,3'E)-3,3'-[(2-Sulfanylidene-1,3-dithiole-4,5-diyl)bis(sulfanediyl)]bis(4-hydroxypent-3-en-2-one)

Crystal data

$\mathrm{C}_{13} \mathrm{H}_{14} \mathrm{O}_{4} \mathrm{~S}_{5}$

$M_{r}=394.54$

Triclinic, $P \overline{1}$

$a=7.1843(1) \AA$

$b=9.9198(1) \AA$

$c=12.5230(2) \AA$

$\alpha=84.319(1)^{\circ}$

$\beta=83.574(1)^{\circ}$

$\gamma=69.151(1)^{\circ}$

$V=827.11(2) \AA^{3}$

$Z=2$

$F(000)=408$

$D_{\mathrm{x}}=1.584 \mathrm{Mg} \mathrm{m}^{-3}$

$\mathrm{Cu} K \alpha$ radiation, $\lambda=1.54184 \AA$

Cell parameters from 38605 reflections

$\theta=3.6-68.9^{\circ}$

$\mu=6.59 \mathrm{~mm}^{-1}$

$T=100 \mathrm{~K}$

Block, light yellow

$0.3 \times 0.28 \times 0.06 \mathrm{~mm}$

Data collection

Rigaku SuperNova HyPix3000

3086 independent reflections diffractometer

$\omega$ scans

Absorption correction: multi-scan (CrysAlisPro; Rigaku OD, 2015)

$T_{\min }=0.208, T_{\max }=0.673$

45972 measured reflections

3034 reflections with $I>2 \sigma(I)$

$R_{\text {int }}=0.048$

$\theta_{\text {max }}=69.1^{\circ}, \theta_{\min }=3.6^{\circ}$

$h=-8 \rightarrow 8$

$k=-12 \rightarrow 12$

$l=-15 \rightarrow 15$

\section{Refinement}

Refinement on $F^{2}$

Least-squares matrix: full

$R\left[F^{2}>2 \sigma\left(F^{2}\right)\right]=0.027$

$w R\left(F^{2}\right)=0.073$

$S=1.05$

3072 reflections

206 parameters

0 restraints 
Primary atom site location: dual

Secondary atom site location: difference Fourier map

Hydrogen site location: mixed

$\mathrm{H}$-atom parameters constrained

$w=1 /\left[\sigma^{2}\left(F_{\mathrm{o}}^{2}\right)+(0.0432 P)^{2}+0.5496 P\right]$

where $P=\left(F_{\mathrm{o}}^{2}+2 F_{\mathrm{c}}^{2}\right) / 3$

\author{
$(\Delta / \sigma)_{\max }=0.001$ \\ $\Delta \rho_{\max }=0.37$ e $\AA^{-3}$ \\ $\Delta \rho_{\min }=-0.31$ e $\AA^{-3}$ \\ Extinction correction: SHELXL-2016/6 \\ (Sheldrick 2015b), \\ $\mathrm{Fc}^{*}=\mathrm{kFc}\left[1+0.001 \times \mathrm{xc}^{2} \lambda^{3} / \sin (2 \theta)\right]^{-1 / 4}$ \\ Extinction coefficient: 0.0023 (3)
}

Special details

Geometry. All esds (except the esd in the dihedral angle between two 1.s. planes) are estimated using the full covariance matrix. The cell esds are taken into account individually in the estimation of esds in distances, angles and torsion angles; correlations between esds in cell parameters are only used when they are defined by crystal symmetry. An approximate (isotropic) treatment of cell esds is used for estimating esds involving 1.s. planes.

Fractional atomic coordinates and isotropic or equivalent isotropic displacement parameters $\left(\AA^{2}\right)$

\begin{tabular}{|c|c|c|c|c|}
\hline & $x$ & $y$ & $z$ & $U_{\text {iso }} * / U_{\text {eq }}$ \\
\hline $\mathrm{S} 1$ & $0.23650(6)$ & $0.66587(4)$ & $0.42463(3)$ & $0.01782(12)$ \\
\hline $\mathrm{S} 2$ & $0.27692(6)$ & $0.63562(4)$ & $0.65943(3)$ & $0.01461(11)$ \\
\hline $\mathrm{S} 3$ & $0.31242(6)$ & $0.48313(4)$ & $0.88104(3)$ & $0.01525(12)$ \\
\hline S4 & $0.24878(6)$ & $0.21427(4)$ & $0.76744(3)$ & $0.01430(11)$ \\
\hline S5 & $0.22936(6)$ & $0.40181(4)$ & $0.55835(3)$ & $0.01485(11)$ \\
\hline $\mathrm{O} 1$ & $0.58163(18)$ & $0.77059(13)$ & $0.86405(10)$ & $0.0219(3)$ \\
\hline $\mathrm{O} 2$ & $0.22982(18)$ & $0.89341(12)$ & $0.91407(10)$ & 0.0208 \\
\hline $\mathrm{H} 2$ & 0.348293 & 0.879765 & 0.896703 & $0.031 *$ \\
\hline $\mathrm{O} 3$ & $0.79489(17)$ & $-0.06088(12)$ & $0.69638(10)$ & $0.0204(3)$ \\
\hline $\mathrm{O} 4$ & $0.56236(18)$ & $-0.12438(12)$ & $0.60106(10)$ & $0.0212(3)$ \\
\hline $\mathrm{H} 4$ & 0.667516 & -0.126626 & 0.622140 & $0.032 *$ \\
\hline $\mathrm{C} 1$ & $0.2480(2)$ & $0.57110(16)$ & $0.54050(13)$ & $0.0137(3)$ \\
\hline $\mathrm{C} 2$ & $0.2827(2)$ & $0.48345(16)$ & $0.74276(13)$ & $0.0129(3)$ \\
\hline $\mathrm{C} 3$ & $0.2616(2)$ & $0.37325(16)$ & $0.69608(13)$ & $0.0129(3)$ \\
\hline $\mathrm{C} 4$ & $0.7301(3)$ & $0.5227(2)$ & $0.83018(15)$ & $0.0232(4)$ \\
\hline $\mathrm{H} 4 \mathrm{~A}$ & 0.728193 & 0.505999 & 0.756173 & $0.035^{*}$ \\
\hline $\mathrm{H} 4 \mathrm{~B}$ & 0.725804 & 0.439335 & 0.874947 & $0.035^{*}$ \\
\hline $\mathrm{H} 4 \mathrm{C}$ & 0.850316 & 0.540141 & 0.839425 & $0.035^{*}$ \\
\hline C5 & $0.5532(3)$ & $0.65102(18)$ & $0.86127(13)$ & $0.0175(3)$ \\
\hline C6 & $0.3570(2)$ & $0.64631(17)$ & $0.88533(13)$ & $0.0146(3)$ \\
\hline $\mathrm{C} 7$ & $0.1978(2)$ & $0.77374(18)$ & $0.91381(13)$ & $0.0163(3)$ \\
\hline $\mathrm{C} 8$ & -0.0110 & $0.78032(18)$ & $0.94305(15)$ & $0.0206(4)$ \\
\hline H8A & -0.080210 & 0.861593 & 0.985597 & $0.031 *$ \\
\hline H8B & -0.010564 & 0.692988 & 0.983764 & $0.031 *$ \\
\hline $\mathrm{H} 8 \mathrm{C}$ & -0.077272 & 0.790640 & 0.878697 & $0.031 *$ \\
\hline C9 & $0.6980(3)$ & $0.13033(18)$ & $0.81362(15)$ & $0.0213(4)$ \\
\hline H9A & 0.632959 & 0.118292 & 0.883274 & $0.032 *$ \\
\hline H9B & 0.650861 & 0.230598 & 0.789056 & $0.032 *$ \\
\hline $\mathrm{H} 9 \mathrm{C}$ & 0.839859 & 0.097756 & 0.818419 & $0.032 *$ \\
\hline $\mathrm{C} 10$ & $0.6520(2)$ & $0.04366(17)$ & $0.73592(14)$ & $0.0170(3)$ \\
\hline $\mathrm{C} 11$ & $0.4523(2)$ & $0.07528(16)$ & $0.70716(13)$ & $0.0148(3)$ \\
\hline C12 & $0.4160(2)$ & $-0.01363(17)$ & $0.63824(14)$ & $0.0168(3)$ \\
\hline
\end{tabular}




\begin{tabular}{lllll}
$\mathrm{C} 13$ & $0.2157(3)$ & $0.00525(18)$ & $0.60412(15)$ & $0.0203(4)$ \\
$\mathrm{H} 13 \mathrm{~A}$ & 0.231343 & -0.053312 & 0.544829 & $0.030^{*}$ \\
$\mathrm{H} 13 \mathrm{~B}$ & 0.148642 & 0.104954 & 0.582310 & $0.030^{*}$ \\
$\mathrm{H} 13 \mathrm{C}$ & 0.137979 & -0.023707 & 0.663218 & $0.030^{*}$ \\
\hline
\end{tabular}

Atomic displacement parameters $\left(\AA^{2}\right)$

\begin{tabular}{lllllll}
\hline & $U^{11}$ & $U^{22}$ & $U^{33}$ & $U^{12}$ & $U^{13}$ & $U^{23}$ \\
\hline S1 & $0.0235(2)$ & $0.0160(2)$ & $0.0145(2)$ & $-0.00766(16)$ & $-0.00267(16)$ & $0.00069(15)$ \\
S2 & $0.0234(2)$ & $0.00936(19)$ & $0.0133(2)$ & $-0.00776(15)$ & $-0.00300(15)$ & $-0.00126(14)$ \\
S3 & $0.0252(2)$ & $0.0117(2)$ & $0.0117(2)$ & $-0.00935(15)$ & $-0.00231(15)$ & $-0.00187(14)$ \\
S4 & $0.0192(2)$ & $0.00921(19)$ & $0.0154(2)$ & $-0.00658(15)$ & $0.00134(15)$ & $-0.00193(15)$ \\
S5 & $0.0223(2)$ & $0.01119(19)$ & $0.0137(2)$ & $-0.00800(15)$ & $-0.00379(15)$ & $-0.00224(14)$ \\
O1 & $0.0268(6)$ & $0.0210(6)$ & $0.0239(7)$ & $-0.0153(5)$ & $-0.0035(5)$ & $-0.0008(5)$ \\
O2 & $0.0266(6)$ & $0.0135(6)$ & $0.0254(7)$ & $-0.0100(5)$ & $-0.0020(5)$ & $-0.0051(5)$ \\
O3 & $0.0195(6)$ & $0.0155(6)$ & $0.0250(7)$ & $-0.0051(5)$ & $-0.0005(5)$ & $-0.0012(5)$ \\
O4 & $0.0227(6)$ & $0.0145(6)$ & $0.0259(7)$ & $-0.0046(5)$ & $-0.0007(5)$ & $-0.0076(5)$ \\
C1 & $0.0137(7)$ & $0.0102(7)$ & $0.0173(8)$ & $-0.0036(6)$ & $-0.0020(6)$ & $-0.0029(6)$ \\
C2 & $0.0153(7)$ & $0.0113(7)$ & $0.0120(8)$ & $-0.0046(6)$ & $-0.0007(6)$ & $-0.0013(6)$ \\
C3 & $0.0161(7)$ & $0.0101(7)$ & $0.0127(8)$ & $-0.0047(6)$ & $-0.0016(6)$ & $-0.0011(6)$ \\
C4 & $0.0216(8)$ & $0.0263(9)$ & $0.0233(9)$ & $-0.0089(7)$ & $-0.0015(7)$ & $-0.0072(7)$ \\
C5 & $0.0247(8)$ & $0.0186(8)$ & $0.0114(8)$ & $-0.0096(7)$ & $-0.0048(6)$ & $-0.0006(6)$ \\
C6 & $0.0223(8)$ & $0.0128(7)$ & $0.0119(8)$ & $-0.0093(6)$ & $-0.0030(6)$ & $-0.0022(6)$ \\
C7 & $0.0256(8)$ & $0.0161(8)$ & $0.0097(8)$ & $-0.0093(7)$ & $-0.0047(6)$ & $-0.0011(6)$ \\
C8 & $0.0224(8)$ & $0.0163(8)$ & $0.0227(9)$ & $-0.0061(7)$ & $-0.0001(7)$ & $-0.0041(7)$ \\
C9 & $0.0256(9)$ & $0.0185(8)$ & $0.0221(9)$ & $-0.0089(7)$ & $-0.0070(7)$ & $-0.0017(7)$ \\
C10 & $0.0237(8)$ & $0.0110(7)$ & $0.0166(8)$ & $-0.0076(6)$ & $-0.0004(6)$ & $0.0027(6)$ \\
C11 & $0.0194(8)$ & $0.0083(7)$ & $0.0166(8)$ & $-0.0055(6)$ & $0.0004(6)$ & $-0.0008(6)$ \\
C12 & $0.0236(8)$ & $0.0105(7)$ & $0.0170(8)$ & $-0.0079(6)$ & $0.0013(6)$ & $0.0004(6)$ \\
C13 & $0.0246(8)$ & $0.0137(8)$ & $0.0252(9)$ & $-0.0091(7)$ & $-0.0021(7)$ & $-0.0047(7)$ \\
& & & & & & \\
\hline & & & & & & \\
\hline
\end{tabular}

Geometric parameters $\left(\AA,^{\circ}\right)$

\begin{tabular}{llll}
\hline $\mathrm{S} 1-\mathrm{C} 1$ & $1.6424(17)$ & $\mathrm{C} 4-\mathrm{H} 4 \mathrm{C}$ & 0.9600 \\
$\mathrm{~S} 2-\mathrm{C} 1$ & $1.7389(16)$ & $\mathrm{C} 4-\mathrm{C} 5$ & $1.491(2)$ \\
$\mathrm{S} 2-\mathrm{C} 2$ & $1.7385(16)$ & $\mathrm{C} 5-\mathrm{C} 6$ & $1.424(2)$ \\
$\mathrm{S} 3-\mathrm{C} 2$ & $1.7679(16)$ & $\mathrm{C} 6-\mathrm{C} 7$ & $1.415(2)$ \\
$\mathrm{S} 3-\mathrm{C} 6$ & $1.7653(16)$ & $\mathrm{C} 7-\mathrm{C} 8$ & $1.483(2)$ \\
$\mathrm{S} 4-\mathrm{C} 3$ & $1.7608(16)$ & $\mathrm{C} 8-\mathrm{H} 8 \mathrm{~A}$ & 0.9600 \\
$\mathrm{~S} 4-\mathrm{C} 11$ & $1.7700(16)$ & $\mathrm{C} 8-\mathrm{H} 8 \mathrm{~B}$ & 0.9600 \\
$\mathrm{~S} 5-\mathrm{C} 1$ & $1.7225(16)$ & $\mathrm{C} 8-\mathrm{H} 8 \mathrm{C}$ & 0.9600 \\
$\mathrm{~S} 5-\mathrm{C} 3$ & $1.7479(16)$ & $\mathrm{C} 9-\mathrm{H} 9 \mathrm{~A}$ & 0.9600 \\
$\mathrm{O} 1-\mathrm{C} 5$ & $1.278(2)$ & $\mathrm{C} 9-\mathrm{H} 9 \mathrm{~B}$ & 0.9600 \\
$\mathrm{O} 2-\mathrm{H} 2$ & 0.8200 & $\mathrm{C} 9-\mathrm{H} 9 \mathrm{C}$ & 0.9600 \\
$\mathrm{O} 2-\mathrm{C} 7$ & $1.287(2)$ & $\mathrm{C} 9-\mathrm{C} 10$ & $1.495(2)$ \\
$\mathrm{O} 3-\mathrm{C} 10$ & $1.267(2)$ & $\mathrm{C} 10-\mathrm{C} 11$ & $1.435(2)$ \\
$\mathrm{O} 4-\mathrm{H} 4$ & 0.8200 & $\mathrm{C} 11-\mathrm{C} 12$ & $1.399(2)$ \\
$\mathrm{O} 4-\mathrm{C} 12$ & $1.303(2)$ & $\mathrm{C} 12-\mathrm{C} 13$ & $1.489(2)$
\end{tabular}




\begin{tabular}{|c|c|c|c|}
\hline $\mathrm{C} 2-\mathrm{C} 3$ & $1.351(2)$ & $\mathrm{C} 13-\mathrm{H} 13 \mathrm{~A}$ & 0.9600 \\
\hline $\mathrm{C} 4-\mathrm{H} 4 \mathrm{~A}$ & 0.9600 & $\mathrm{C} 13-\mathrm{H} 13 \mathrm{~B}$ & 0.9600 \\
\hline $\mathrm{C} 4-\mathrm{H} 4 \mathrm{~B}$ & 0.9600 & $\mathrm{C} 13-\mathrm{H} 13 \mathrm{C}$ & 0.9600 \\
\hline $\mathrm{C} 10 \cdots \mathrm{O} 1^{\mathrm{i}}$ & $3.178(2)$ & $\mathrm{S} 3 \cdots \mathrm{C} 5^{\mathrm{iii}}$ & $3.471(2)$ \\
\hline $\mathrm{C} 12 \cdots \mathrm{O} 4^{\mathrm{ii}}$ & $3.180(2)$ & $\mathrm{S} 5 \cdots \mathrm{S} 5^{\text {iv }}$ & $3.5688(6)$ \\
\hline $\mathrm{C} 13 \cdots \mathrm{O} 4^{\mathrm{ii}}$ & $3.219(2)$ & & \\
\hline $\mathrm{C} 2-\mathrm{S} 2-\mathrm{C} 1$ & $97.02(7)$ & $\mathrm{C} 6-\mathrm{C} 7-\mathrm{C} 8$ & $123.84(15)$ \\
\hline $\mathrm{C} 6-\mathrm{S} 3-\mathrm{C} 2$ & $101.45(7)$ & $\mathrm{C} 7-\mathrm{C} 8-\mathrm{H} 8 \mathrm{~A}$ & 109.5 \\
\hline $\mathrm{C} 3-\mathrm{S} 4-\mathrm{C} 11$ & $103.72(7)$ & $\mathrm{C} 7-\mathrm{C} 8-\mathrm{H} 8 \mathrm{~B}$ & 109.5 \\
\hline $\mathrm{C} 1-\mathrm{S} 5-\mathrm{C} 3$ & $97.48(7)$ & $\mathrm{C} 7-\mathrm{C} 8-\mathrm{H} 8 \mathrm{C}$ & 109.5 \\
\hline $\mathrm{C} 7-\mathrm{O} 2-\mathrm{H} 2$ & 109.5 & $\mathrm{H} 8 \mathrm{~A}-\mathrm{C} 8-\mathrm{H} 8 \mathrm{~B}$ & 109.5 \\
\hline $\mathrm{C} 12-\mathrm{O} 4-\mathrm{H} 4$ & 109.5 & $\mathrm{H} 8 \mathrm{~A}-\mathrm{C} 8-\mathrm{H} 8 \mathrm{C}$ & 109.5 \\
\hline $\mathrm{S} 1-\mathrm{C} 1-\mathrm{S} 2$ & $122.31(9)$ & $\mathrm{H} 8 \mathrm{~B}-\mathrm{C} 8-\mathrm{H} 8 \mathrm{C}$ & 109.5 \\
\hline $\mathrm{S} 1-\mathrm{C} 1-\mathrm{S} 5$ & $124.58(10)$ & $\mathrm{H} 9 \mathrm{~A}-\mathrm{C} 9-\mathrm{H} 9 \mathrm{~B}$ & 109.5 \\
\hline $\mathrm{S} 5-\mathrm{C} 1-\mathrm{S} 2$ & $113.10(9)$ & $\mathrm{H} 9 \mathrm{~A}-\mathrm{C} 9-\mathrm{H} 9 \mathrm{C}$ & 109.5 \\
\hline $\mathrm{S} 2-\mathrm{C} 2-\mathrm{S} 3$ & $118.79(9)$ & $\mathrm{H} 9 \mathrm{~B}-\mathrm{C} 9-\mathrm{H} 9 \mathrm{C}$ & 109.5 \\
\hline $\mathrm{C} 3-\mathrm{C} 2-\mathrm{S} 2$ & $116.65(13)$ & $\mathrm{C} 10-\mathrm{C} 9-\mathrm{H} 9 \mathrm{~A}$ & 109.5 \\
\hline $\mathrm{C} 3-\mathrm{C} 2-\mathrm{S} 3$ & $124.56(13)$ & $\mathrm{C} 10-\mathrm{C} 9-\mathrm{H} 9 \mathrm{~B}$ & 109.5 \\
\hline $\mathrm{S} 5-\mathrm{C} 3-\mathrm{S} 4$ & $120.39(9)$ & $\mathrm{C} 10-\mathrm{C} 9-\mathrm{H} 9 \mathrm{C}$ & 109.5 \\
\hline $\mathrm{C} 2-\mathrm{C} 3-\mathrm{S} 4$ & $123.78(13)$ & $\mathrm{O} 3-\mathrm{C} 10-\mathrm{C} 9$ & $118.05(15)$ \\
\hline $\mathrm{C} 2-\mathrm{C} 3-\mathrm{S} 5$ & $115.69(12)$ & $\mathrm{O} 3-\mathrm{C} 10-\mathrm{C} 11$ & $120.25(15)$ \\
\hline $\mathrm{H} 4 \mathrm{~A}-\mathrm{C} 4-\mathrm{H} 4 \mathrm{~B}$ & 109.5 & $\mathrm{C} 11-\mathrm{C} 10-\mathrm{C} 9$ & $121.69(14)$ \\
\hline $\mathrm{H} 4 \mathrm{~A}-\mathrm{C} 4-\mathrm{H} 4 \mathrm{C}$ & 109.5 & $\mathrm{C} 10-\mathrm{C} 11-\mathrm{S} 4$ & $120.87(12)$ \\
\hline $\mathrm{H} 4 \mathrm{~B}-\mathrm{C} 4-\mathrm{H} 4 \mathrm{C}$ & 109.5 & $\mathrm{C} 12-\mathrm{C} 11-\mathrm{S} 4$ & $119.52(12)$ \\
\hline $\mathrm{C} 5-\mathrm{C} 4-\mathrm{H} 4 \mathrm{~A}$ & 109.5 & $\mathrm{C} 12-\mathrm{C} 11-\mathrm{C} 10$ & $119.34(14)$ \\
\hline $\mathrm{C} 5-\mathrm{C} 4-\mathrm{H} 4 \mathrm{~B}$ & 109.5 & $\mathrm{O} 4-\mathrm{C} 12-\mathrm{C} 11$ & $120.13(15)$ \\
\hline $\mathrm{C} 5-\mathrm{C} 4-\mathrm{H} 4 \mathrm{C}$ & 109.5 & $\mathrm{O} 4-\mathrm{C} 12-\mathrm{C} 13$ & $115.14(14)$ \\
\hline $\mathrm{O} 1-\mathrm{C} 5-\mathrm{C} 4$ & $117.29(15)$ & $\mathrm{C} 11-\mathrm{C} 12-\mathrm{C} 13$ & $124.71(15)$ \\
\hline $\mathrm{O} 1-\mathrm{C} 5-\mathrm{C} 6$ & $119.46(15)$ & $\mathrm{C} 12-\mathrm{C} 13-\mathrm{H} 13 \mathrm{~A}$ & 109.5 \\
\hline $\mathrm{C} 6-\mathrm{C} 5-\mathrm{C} 4$ & $123.24(15)$ & $\mathrm{C} 12-\mathrm{C} 13-\mathrm{H} 13 \mathrm{~B}$ & 109.5 \\
\hline $\mathrm{C} 5-\mathrm{C} 6-\mathrm{S} 3$ & $120.55(12)$ & $\mathrm{C} 12-\mathrm{C} 13-\mathrm{H} 13 \mathrm{C}$ & 109.5 \\
\hline $\mathrm{C} 7-\mathrm{C} 6-\mathrm{S} 3$ & $120.13(12)$ & $\mathrm{H} 13 \mathrm{~A}-\mathrm{C} 13-\mathrm{H} 13 \mathrm{~B}$ & 109.5 \\
\hline $\mathrm{C} 7-\mathrm{C} 6-\mathrm{C} 5$ & $119.32(14)$ & $\mathrm{H} 13 \mathrm{~A}-\mathrm{C} 13-\mathrm{H} 13 \mathrm{C}$ & 109.5 \\
\hline $\mathrm{O} 2-\mathrm{C} 7-\mathrm{C} 6$ & $119.97(15)$ & $\mathrm{H} 13 \mathrm{~B}-\mathrm{C} 13-\mathrm{H} 13 \mathrm{C}$ & 109.5 \\
\hline $\mathrm{O} 2-\mathrm{C} 7-\mathrm{C} 8$ & $116.18(15)$ & & \\
\hline $\mathrm{S} 2-\mathrm{C} 2-\mathrm{C} 3-\mathrm{S} 4$ & $-176.18(8)$ & $\mathrm{C} 2-\mathrm{S} 3-\mathrm{C} 6-\mathrm{C} 5$ & $-84.62(14)$ \\
\hline $\mathrm{S} 2-\mathrm{C} 2-\mathrm{C} 3-\mathrm{S} 5$ & $-0.54(18)$ & $\mathrm{C} 2-\mathrm{S} 3-\mathrm{C} 6-\mathrm{C} 7$ & $95.98(14)$ \\
\hline $\mathrm{S} 3-\mathrm{C} 2-\mathrm{C} 3-\mathrm{S} 4$ & $3.1(2)$ & $\mathrm{C} 3-\mathrm{S} 4-\mathrm{C} 11-\mathrm{C} 10$ & 80.09 (14) \\
\hline $\mathrm{S} 3-\mathrm{C} 2-\mathrm{C} 3-\mathrm{S} 5$ & $178.72(8)$ & $\mathrm{C} 3-\mathrm{S} 4-\mathrm{C} 11-\mathrm{C} 12$ & $-105.92(14)$ \\
\hline $\mathrm{S} 3-\mathrm{C} 6-\mathrm{C} 7-\mathrm{O} 2$ & $-178.14(12)$ & $\mathrm{C} 3-\mathrm{S} 5-\mathrm{C} 1-\mathrm{S} 1$ & $178.43(11)$ \\
\hline $\mathrm{S} 3-\mathrm{C} 6-\mathrm{C} 7-\mathrm{C} 8$ & $1.0(2)$ & $\mathrm{C} 3-\mathrm{S} 5-\mathrm{C} 1-\mathrm{S} 2$ & $-2.54(10)$ \\
\hline $\mathrm{S} 4-\mathrm{C} 11-\mathrm{C} 12-\mathrm{O} 4$ & $-173.78(12)$ & $\mathrm{C} 4-\mathrm{C} 5-\mathrm{C} 6-\mathrm{S} 3$ & $0.8(2)$ \\
\hline $\mathrm{S} 4-\mathrm{C} 11-\mathrm{C} 12-\mathrm{C} 13$ & $4.5(2)$ & $\mathrm{C} 4-\mathrm{C} 5-\mathrm{C} 6-\mathrm{C} 7$ & $-179.82(15)$ \\
\hline $\mathrm{O} 1-\mathrm{C} 5-\mathrm{C} 6-\mathrm{S} 3$ & $179.45(12)$ & $\mathrm{C} 5-\mathrm{C} 6-\mathrm{C} 7-\mathrm{O} 2$ & $2.4(2)$ \\
\hline $\mathrm{O} 1-\mathrm{C} 5-\mathrm{C} 6-\mathrm{C} 7$ & $-1.1(2)$ & $\mathrm{C} 5-\mathrm{C} 6-\mathrm{C} 7-\mathrm{C} 8$ & $-178.41(15)$ \\
\hline
\end{tabular}




$\begin{array}{llll}\mathrm{O} 3-\mathrm{C} 10-\mathrm{C} 11-\mathrm{S} 4 & 176.35(12) & \mathrm{C} 6-\mathrm{S} 3-\mathrm{C} 2-\mathrm{S} 2 & -6.57(11) \\ \mathrm{O} 3-\mathrm{C} 10-\mathrm{C} 11-\mathrm{C} 12 & 2.3(2) & \mathrm{C} 6-\mathrm{S} 3-\mathrm{C} 2-\mathrm{C} 3 & 174.19(14) \\ \mathrm{C} 1-\mathrm{S} 2-\mathrm{C} 2-\mathrm{S} 3 & 179.61(9) & \mathrm{C} 9-\mathrm{C} 10-\mathrm{C} 11-\mathrm{S} 4 & -2.8(2) \\ \mathrm{C} 1-\mathrm{S} 2-\mathrm{C} 2-\mathrm{C} 3 & -1.09(14) & \mathrm{C} 9-\mathrm{C} 10-\mathrm{C} 11-\mathrm{C} 12 & -176.84(15) \\ \mathrm{C} 1-\mathrm{S} 5-\mathrm{C} 3-\mathrm{S} 4 & 177.69(10) & \mathrm{C} 10-\mathrm{C} 11-\mathrm{C} 12-\mathrm{O} 4 & 0.3(2) \\ \mathrm{C} 1-\mathrm{S} 5-\mathrm{C} 3-\mathrm{C} 2 & 1.89(14) & \mathrm{C} 10-\mathrm{C} 11-\mathrm{C} 12-\mathrm{C} 13 & 178.60(15) \\ \mathrm{C} 2-\mathrm{S} 2-\mathrm{C} 1-\mathrm{S} 1 & -178.63(10) & \mathrm{C} 11-\mathrm{S} 4-\mathrm{C} 3-\mathrm{S} 5 & 63.50(11) \\ \mathrm{C} 2-\mathrm{S} 2-\mathrm{C} 1-\mathrm{S} 5 & 2.31(10) & \mathrm{C} 11-\mathrm{S} 4-\mathrm{C} 3-\mathrm{C} 2 & -121.05(15)\end{array}$

Symmetry codes: (i) $x, y-1, z$; (ii) $-x+1,-y,-z+1$; (iii) $-x+1,-y+1,-z+2$; (iv) $-x,-y+1,-z+1$.

Hydrogen-bond geometry $\left(\AA,{ }^{\circ}\right)$

\begin{tabular}{lllll}
\hline$D-\mathrm{H} \cdots A$ & $D-\mathrm{H}$ & $\mathrm{H} \cdots A$ & $D \cdots A$ & $D-\mathrm{H} \cdots A$ \\
\hline $\mathrm{O} 2-\mathrm{H} 2 \cdots \mathrm{O} 1$ & 0.82 & 1.67 & $2.4228(17)$ & 151 \\
$\mathrm{O} 4-\mathrm{H} 4 \cdots \mathrm{O} 3$ & 0.82 & 1.69 & $2.4406(17)$ & 151 \\
$\mathrm{C} 13-\mathrm{H} 13 C \cdots \mathrm{O}^{\mathrm{v}}$ & 0.96 & 2.60 & $3.374(3)$ & 138 \\
$\mathrm{C} 8-\mathrm{H} 8 C \cdots \mathrm{O}^{\text {vi }}$ & 0.96 & 2.66 & $3.522(2)$ & 150 \\
$\mathrm{C} 8-\mathrm{H} 8 A \cdots \mathrm{O} 2^{\text {vii }}$ & 0.96 & 2.66 & $3.612(2)$ & 170 \\
$\mathrm{C} 8-\mathrm{H} 8 C \cdots{ }^{v}$ & 0.96 & 2.56 & $3.228(3)$ & 127 \\
$\mathrm{C} 9-\mathrm{H} 9 B \cdots{ }^{v}$ & 0.96 & 2.90 & $3.5184(19)$ & 123 \\
$\mathrm{C} 13-\mathrm{H} 13 B \cdots \mathrm{S} 1^{\text {vii }}$ & 0.96 & 2.89 & $3.7165(19)$ & 144 \\
$\mathrm{C} 4-\mathrm{H} 4 A \cdots \mathrm{S} 1^{\text {viii }}$ & 0.96 & 2.90 & $3.7987(19)$ & 156
\end{tabular}

Symmetry codes: (iv) $-x,-y+1,-z+1$; (v) $x-1, y, z$; (vi) $x-1, y+1, z$; (vii) $-x,-y+2,-z+2$; (viii) $-x+1,-y+1,-z+1$.

Selected bond lengths $(\AA)$ and angles $\left(^{\circ}\right)$

\begin{tabular}{ll}
\hline $\mathrm{C} 1=\mathrm{S} 1$ & $1.6424(17)$ \\
$\mathrm{C} 2=\mathrm{C} 3$ & $1.351(2)$ \\
$\mathrm{S} 2-\mathrm{C} 2$ & $1.7385(16)$ \\
$\mathrm{S} 3-\mathrm{C} 2$ & $1.7679(16)$ \\
$\mathrm{S} 5-\mathrm{C} 3$ & $1.7479(16)$ \\
$\mathrm{S} 4-\mathrm{C} 3$ & $1.7608(16)$ \\
O1=C5 & $1.278(2)$ \\
O2-C7 & $1.287(2)$ \\
O3=C10 & $1.267(2)$ \\
O4-C12 & $1.303(2)$ \\
O2-H2 & 0.8200 \\
O4-H4 & 0.8200 \\
S2-C2-S3 & $118.79(9)$ \\
S5-C3-S4 & $120.39(9)$ \\
C6-S3-C2 & $101.45(7)$ \\
C3-S4-C11 & $103.72(7)$ \\
C7-C6-C5 & $119.32(14)$ \\
C12-C11-C10 & $119.34(14)$ \\
\end{tabular}

